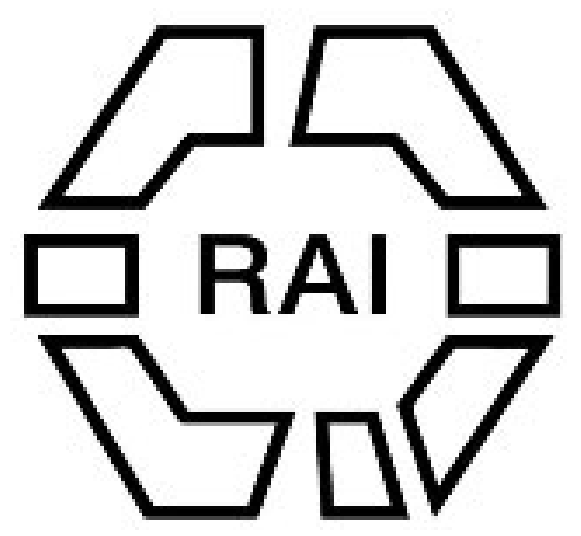

Address to the Anthropological Section of the British Association at Manchester Author(s): A. H. Sayce

Source: The Tournal of the Anthropological Institute of Great Britain and Ireland, Vol. 17 (1888), pp. 166-181

Published by: Royal Anthropological Institute of Great Britain and Ireland

Stable URL: http://www.jstor.org/stable/2841598

Accessed: 15/06/2014 04:03

Your use of the JSTOR archive indicates your acceptance of the Terms \& Conditions of Use, available at http://www.jstor.org/page/info/about/policies/terms.jsp

JSTOR is a not-for-profit service that helps scholars, researchers, and students discover, use, and build upon a wide range of content in a trusted digital archive. We use information technology and tools to increase productivity and facilitate new forms of scholarship. For more information about JSTOR, please contact support@jstor.org. 


\section{ANTHROPOLOGICAL MISCELLANEA.}

\section{Address to the Anthropological Section of the British Association at ManChester.}

By Prof. A. H. SAYce, M.A., President of the Section.

SURPRISE has sometimes been expressed that anthropology, the science of man, should have been the last of the sciences to come into being. But the fact is not so strange as it seems at first sight to be. Science originated in curiosity, and the curiosity of primitive man, like the curiosity of a child, was first exercised upon the objects around him. The fact that we are separate from the world about us, and that the world about us is our own creation, is a conviction which grows but slowly in the mind either of the individual or of the race in general. "The child says, "Charley likes this," before he learns to say, "I like this," and in most languages the objective case of the personal pronoun exhibits earlier forms than the nominative.

Moreover, it is only through the relations that exist between mankind and external nature that we can arrive at anything like a scientific knowledge of man. Science, it must be remembered, implies the discovery of general laws, and general laws are only possible if we deal, not with the single individual, but with individuals when grouped together in races, tribes, or communities. We can never take a photograph of the mind of an individual, but we can come to know the principles that govern the actions of bodies of men, and can employ the inductive method of science to discover the physical and moral characteristics of tribes and races. It is through the form of the skull, the nature of the language, the manners and customs, or the religious ideas of a people that we can gain a true conception of their history and character. The thinker who wishes to carry out the precept of the Delphian oracle and to "know himself" must study himself as reflected in the community to which he belongs. The sum of the sciences which deal with the relations of the community to the external world will constitute the science of anthropology.

The field occupied by the science is a vast one, and the several workers in it must be content to cultivate portions of it only. The age of "admirable Crichtons" is past; it would be impossible for a single student to cover with equal success the whole domain of anthropology. All that he can hope to do is to share the labour 
with others, and to concentrate his energies on but one or two departments in the wide field of research. A day may come when the work we have to perform will be accomplished, and our successors will reap the harvest that we have sown. But meanwhile we must each keep to our own special line of investigation, asking only that others whose studies have lain in a different direction shall help us with the results they have obtained.

I shall therefore make no apology for confining myself on the present occasion to those branches of anthropological study about which I know most. It is more particularly to the study of language, and the evidence we may derive from it as to the history and development of mankind, that I wish to direct your attention. It is in language that the thoughts and feelings of man are mirrored and embodied; it is through language that we learn the little we know about what is passing in the minds of others. Language is not only a means of intercommunication, it is also a record of the ideas and beliefs, the emotions and the hopes of the past generations of the world. In spoken language, accordingly, we may discover the fossilised records of early humanity, as well as the reflection of the thoughts that move the society of to-day. What fossils are to the geologist words are to the comparative philologist.

But we must be careful not to press the testimony of language beyond its legitimate limits. Language is essentially a social product, the creation of a community of men living together and moved by the same wants and desires. It is one of the chief bonds that bind a community together, and its existence and development depend upon the community to which it belongs. If the community is changed by conquest or intermarriage or any other cause the language of the community changes too. The individual who quits one community for another has at the same time to shift his language. The Frenchman who naturalises himself in England must acquire English ; the negro who is born in the United States must adopt the language that is spoken there.

Language is thus a characteristic of a community, and not of an individual. The neglect of this fact has introduced untold mischief not only into philology, but into ethnology as well. Race and language have been confused together, and the fact that a man speaks a particular language has too often been assumed, in spite of daily experience, to prove that he belongs to a particular race. When scholars had discovered that the Sanskrit of India belonged to the same linguistic family as the European languages, they jumped to the conclusion that the dark-skinned Hindu and the light-haired Scandinavian must also belong to one and the same race. Time after time have $\mathrm{I}$ taken up books which sought to determine the racial affinities of sarage or barbarous tribes by means of their language. Language and race, in short, have been used as synonymous terms.

The fallacy is still so common, still so frequently peeps out where we should least expect it, that I think it is hardly superfluous, 
even now, to draw attention to it. And yet we have only to look around us to see how contrary it is to all the facts of experience. We Englishmen are bound together by a common language, but the historian and the craniologist will alike tell us that the blood that runs in our veins is derived from a very various ancestry. Kelt and Teuton, Scandinavian and Roman have struggled together for the mastery in our island since it first came within the horizon of history, and in the remoter days of which history and tradition are silent archæology assures us that there were yet other races who fought and mingled together. The Jews have wandered through the world adopting the languages of the peoples among whom they have settled, and in Transylvania they even look upon an old form of Spanish as their sacred tongue. The Cornishman now speaks English; is he on that account less of a Kelt than the Welshman or the Breton?

Language, however, is not wholly without value to the ethnologist. Though a common language is not a test of race, it is a test of social contact. And social contact may mean-indeed very generally does mean-a certain amount of intermarriage as well. The penal laws passed against the Welsh in the fifteenth century were not suffcient to prevent marriages now and then between the Welsh and the English, and in spite of the social ostracism of the negro in the Northern States of America intermarriages have taken place there between the black and the white population. But in the case of such intermarrying the racial traits of one member only of the union are, as a general rule, preserved. The physical and moral type of the stronger parent prevails in the end, though it is often not easy to tell beforehand on which side the strength will lie. Sometimes, indeed, the physical and moral characters are not inherited together, the child following one of his parents in physical type while he inherits his moral and intellectual qualities from another. But even in such cases the types preserve a wonderful fixity, and testify to the difficulty of changing what we call the characteristics of race.

Herein lies one of the most obvious differences between race and language, a difference which is of itself sufficient to show how impossible it must be to argue from the one to the other. While the characteristics of race seem almost indelible, language is as fluctuating and variable as the waves of the sea. It is perpetually changing in the mouths of its speakers; nay, the individual can even forget the language of his childhood and acquire another which has not the remotest connection with it. A man cannot rid himself of the characteristics of race, but his language is like his clothing which he can strip off and change almost at will.

It seems to me that this is a fact of which only one explanation is possible. The distinctions of race must be older than the distinctions of language. On the monuments of Egypt, more than four thousand years ago, the Libyans are represented with the same fair European complexion as that of the modern Kabyles, and the painted tomb of Rekh-mâ-ra, a Theban prince who lived in the 
sixteenth century before our era, portrays the black-skinned negro, the olive-coloured Syrian, and the red-skinned Egyptian with all the physical peculiarities that distinguish their descendants to-day. The Egyptian language has ceased to be spoken even in its latest Coptic form, but the wooden figure of the "Sheikh el-beled" in the Bulaq Museum, carved 6,000 years ago, reproduces the features of many a fellah in the modern villages of the Nile. Within the limits of history racial characteristics have undergone no change.

I see, therefore, no escape from the conclusion that the chief distinctions of race were established long before man acquired language. If the statement made by M. de Mortillet is true, that the absence of the mental tubercle, or bony excrescence in which the tongue is inserted, in a skull of the Neanderthal type found at La Naulette, indicates an absence of the faculty of speech, one race at least of palæolithic man would have existed in Europe before it had as yet invented an articulate language. Indeed, it is difficult to believe that man has known how to speak for any very great length of time. On the one hand, it is true, languages may remain fixed and almost stationary for a long series of generations. Of this the Semitic languages afford a conspicuous example. Not only the very words, but even the very forms of grammar are still used by the Bedouin of Central Arabia that were employed by the Semitic Babylonians on their monuments five thousand years ago. At that early date the Semitic family of speech already existed with all its peculiarities, which have survived with but little alteration up to the present day. And when it is remembered that Old Egyptian, which comes before us as a literary and decaying language a thousand years earlier, was probably a sister of the parent Semitic speech, the period to which we must assign the formation and development of the latter cannot fall much short of ten thousand years before the Christian era. But on the other hand there is no language which does not bear upon its face the marks of its origin. We can still trace through the thin disguise of subsequent modifications and growth the elements, both lexical and grammatical, out of which language must have arisen. The Bushman dialects still preserve the inarticulate clicks which preceded articulate sounds in expressing ideas; behind the roots which the philologist discovers in allied groups of words lie, plainly visible, the imitations of nataral sounds, or the instinctive utterances of human emotion; while the grammar of languages like Eskimaux or the Aztec of Mexico carries us back to the first mechanism for conveying the meaning of one speaker to another. The beginnings of articulate language are still too transparent to allow us to refer them to a very remote era. I once calculated that from thirty to forty thousand years is the utmost limit that we can allow to man as a speaking animal. In fact, the evidence that he is a drawing animal, derived from the pictured bones and horns of the palæolithic age, mounts back to a much earlier epoch than the evidence that he is a speaking animal.

Mr. Horatio Hale has lately started a very ingenious theory to 
account, not indeed for the origin of language in general, but for the origin of that vast number of apparently unallied families of speech which have existed in the world. He has come across examples of children who have invented and used languages of their own, refusing at the same time to speak the language they heard around them. As the children belonged to civilised com. munities the languages they invented did not spread beyond themselves, and after a time were forgotten by their own inventors. In an uncivilised community, however, it is quite conceivable that such a language might continue to be used by the children after they had begun to grow up and be communicated by them to their descendants. In this casè a wholly new language would be started, which would have no affinities with any other, and after splitting into dialects would become the parent of numerous derived tongues. I must confess that the evidence brought forward by $\mathrm{Mr}$. Hale in support of his theory is not quite convincing to me. It has yet to be proved that the words used by the children to whom he refers were not echoes of the words used by their elders. If they were, a language that originated in them would show more signs of lexical affinity to the older language than is the case with one family of speech when compared with another. On the other hand, the theory would tend to throw light on the curious fact that the morphological divisions of language are also geographical.

By the morphology of a language I mean its structure, that is to say, the mode in which the relations of grammar are expressed in a sentence, and the order in which they occur. These vary considerably, the chief variations being represented by the polysynthetic languages of America, the isolating languages of Eastern Asia, the postfixal languages of Central Asia, the prefixal languages of Africa, and the inflectional languages of Europe and Western Asia. Now it will be observed that each of these classes of language is associated with a particular part of the globe, the isolating languages, for example, being practically confined to Eastern Asia, and the polysynthetic languages to America. Within each class there are numerous families of speech between which no relationship can be discovered beyond that of a common structure; they agree morphologically, but their grammar and lexicon show no signs of connection. If we adopt Mr. Hale's theory we might suppose that the genealogically distinct families of speech grew up in the way he describes, while their morphological agreement would be accounted for by the inherited tendency of their children to run their thinking into a particular mould. The words and contrivances of grammar would be new, the mental framework in which they were set would be an inheritance from former generations.

I have spoken of the inflectional languages as belonging to Europe and Western Asia. This is true if we give a somewhat wide extension to the term inflectional, and make it include not only the Indo-European group, but the Georgian and Semitic groups as well. But, strictly speaking, the Indo-European, or Aryan, languages have a structure of their own, which differs very 
markedly from that of either the Georgian or the Semitic families. The Semitic mode of expressing the relations of grammar, by changing the vowels within a framework of consonants differs as much from the Aryan mode of expressing them by means of suffixes as does the Semitic partiality for words of three consonants from the Indo-European carelessness about the number of syllables in a word. Though it is quite true that the Semitic languages at times approach the Indo-European by using suffixes to denote the forms of grammar, while at other times the Indo-European languages may sulistitute internal vowel change for external flection, nevertheless, in general, the kind of flection employed by the two families of speech is of a totally different character.

This difference of structure, coupled with a complete difference in phonology, grammar, and lexion, has always seemed to me to negative the attempts that have been made to connect the Aryan and Semitic families of language together. The attempts have usually been based on the old confusion between language and race; both Aryans and Semites belong to the white race; therefore it was assumed their languages must be akin. As long as it was generally agreed that the primitive home of the Aryan languages was, like that of the Semitic languages, the western part of Asia, the confusion was excusable. If the earliest seats of the speakers of each were in geographical proximity, there was some reason for believing that languages which were alike spoken by members of the white race, and were alike classed as inflectional, would, when properly questioned, show signs of a common origin.

But that general agreement no longer exisus. While the Asiatic origin of the Semitic languages is beyond dispute, scholars have of late years been coming more and more to the conclusion that Europe was the cradle of the Aryan tongues. Their European origin was first advocated by our countryman Dr. Latham, and was subsequently defended by the eminent comparative philologist Dr. Benfey; but it is only within the last half-dozen years that the theory has won its way to scientific recognition. Different lines of research have been converging towards the same result, and indicating North-eastern Europe as the starting-point of the IndoEuropean languages, while the evidences invoked in favour of their Asiatic origin have one and all broken down.

These evidences chiefly rested on the supposed superiority of Sanskrit over the other Indo-European languages as a representative of the parent-speech from which they were all descended. The grammar and phonology of Sanskrit were imagined to be more archaic, more faithful to the primitive pattern than those of its sister-tongues. It was argued that this implied a less amount of migration and change on the part of its speakers, a nearer residence, in fact, to the region where the parent-speech had once been spoken. As a comparison of the words denoting certain objects in the Indo-European languages showed that this region must have had a cold climate, it was placed on the slopes of the Hindu-Kush or at the sources of the Oxus and Jaxartes. 
But we now know that instead of being the most faithful representative of the parent-speech, Sanskrit is in many respects far less so than are its sister-languages of Europe. Its vocabulary, for instance, has been thrown into confusion by the coalescence of the three primitive vowel sounds $\breve{a}$, $\breve{\text { ĕ }}$ o into the single monotonous $\breve{a}$, a corruption which is paralleled by the coalescence of so many vowels in modern cultivated English in the so-called "neutral" $\partial$. Greek, or even the Lithuanian, which may still be heard to-day from the lips of unlettered peasants, has preserved more faithfully than the Sanskrit of India the features of the parent Aryan. If the faithfulness of the record ${ }^{5}$ is any proof of the geographical proximity of one of the Indo-European languages to their common mother, it is in the neighbourhood of Lithuania, rather than in the neighbourhood of India, that we ought to look for traces of the first home of the Aryan family.

But the theory of the Asiatic origin of the Indo-European family has not only been deprived of its main support by the dethronement of Sanskrit, and the transfer of its prinacy to the languages of Europe, what Professor Max Müller has termed "linguistic palæontology" has further assisted in overthrowing the crumbling edifice. When we find words of similar phonetic form and similar meaning in both the Asiatic and the European branches of the Aryan family-words, too, which it can be shown have not been borrowed by one Indo-European language from another-we are justified in concluding that the objects or phenomena denoted by them were already known to the speakers of the parent language.

Four years ago a valuable contribution to the linguistic palæontology of the Aryan languages was made by Professor Otto Schrader. For the first time the question was approached from the present level of comparative philology, and all words were excluded from comparison which did not satisfy the requirements of phonetic law. The results were sadly disquieting to the be. lievers in that idyllic picture of primitive Aryan life to which we had so long been accustomed. Professor Schrader proved that the speakers of the parent Aryan language must not only have lived in a cold climate - a fact which was known already-but that they must have lived in the stone age, with the skins of wild beasts only to protect them from the rigours of the winter, and nothing better than stone weapons with which to ward off the attacks of savage animals. Their general culture was on a level with their general surroundings. It was little better than that of the Fuegian before he came into contact with European missionaries. The minuteness with which the varying degrees of family relationship were named, instead of indicating an advanced social life, as was formerly imagined, really indicated the direct contrary. The primitive Aryan was indeed acquainted with fire; he could even sew his skins together by means of needles of bone; and possibly could spin a little with the help of rude spindle-whorls; but beyond 
this his knowledge of the arts does not seem to have extended. If he made use of gold or meteoric iron, it was only of the unwrought pieces which he picked up from the ground and employed as ornaments; of the working of metals he was entirely ignorant. But he already practised a kind of rude agriculture, though the art of grinding corn was as yet unknown, and crushed spelt was eaten instead of bread; while the community to which he belonged was essentially that of pastoral nomads, who changed from season to season the miserable beehive huts of wattled mud in which they lived. They could count at least as far as a hundred, and believed in a multitude of ghosts and goblins, making offerings to the dead, and seeing in the bright sky a potent deity.

In calling the speaker of the Aryan parent-speech the primitive Aryan I must not be supposed to be prejudging the question as to the particular race to which he belonged. This is a question which has recently been handled with great ability by an Austrian anthropologist-Dr. Karl Penka. In a remarkable book, published at the end of last year, he endeavours to substantiate the hypothesis advanced in an earlier work, and to show that the first speakers of the Aryan languages were the fair-haired, blue-eyed, light-complexioned dolichocephalic race, which is still found in its greatest purity in Scandinavia; that it was this race which in the neolithic period spread southwards, imposing its yoke upon subject populations, like the Norsemen and Normans of later days, and carrying with it the dialects which afterwards developed into the Aryan languages; and that, finally, it was the same race which in the remote days of the palæolithic age inhabited western and central Europe, where it has left its remains in the typical skulls of Cannstatt and Engis. Dr. Penka would ascribe to its long residence in the semi-arctic climate of palæolithic Europe the permanent blanching of its skin and hair-a form of albinoism which Dr. Poesche in 1878 endeavoured to explain by the climatic conditions of the Rokitno marshes in Russia, where he placed the cradle of the white Aryan race.

It cannot be denied that all the probabilities are at present on Dr. Penka's side, so far as his main contention is concerned. Without denying that the speakers of the Aryan parent speech may have already included slaves or wives of an alien race, it is probable that the majority of them were of one blood. They formed a single community, nomad it is true, and therefore less likely to mix with foreigners, but still sufficiently a single community to speak a language the several dialects of which were so alike as to be mutually intelligible. In the social condition in which the speakers were, and in an age when the waste lands of of the world were still extensive, the greater part of such a community must necessarily, we should think, have belonged to the same race. . . . . Penka has striven to show that the animals whose bones or shells are found in the Scandinavian kitchen-middens are just those whose names are common to the Indo-European languages, or at all events the European section of 
the latter. Now, the skulls disinterred from the prehistoric burialplaces of Denmark and the southern districts of Sweden and Norway are, for the most part, identical with the skulls still characteristic of the Scandinavian population where they accompany a fair skin and light hair and eyes. By combining these two facts we arrive at the conclusion that the fair Scandinavian race is the modern descendant of the race which spoke the parent language of the primitive Aryan community, and left traces of itself in the Scandinavian kitchen-middens. The conclusion is supported by the testimony of history. On the one hand, we have the testimony of classical writers that the Aryan-speaking Kelts of the Christian era were not the dark, small-limbed population which now occupies the larger part of France, but men of large stature, with the blue eyes and fair hair of their Teutonic brethren; while the ideal specimens of humanity conceived of by the aristocratic art of Italy and Greece were the golden-haired Apollo and the blue-eyed Athêne. On the other hand, it was from Scandinavia that in later times other bands of warriors poured forth, who made their way into the countries of the Mediterranean, and even Asia, and established themselves as conquering aristocracies in the midst of subject populations. The Kelts succeeded in reaching Asia Minor, the Scando-German hordes overthrew the Roman empire, the Northmen established themselves from Russia on the east to Iceland and Greenland on the west, and the Normans made Sicily their own long before the days of the German Frederick. The only point in which the later historical irruptions of the Scandinavian peoples differed from their prehistoric ones was, that while the later irruptions were made by sea, the older were made by land. The sail was unknown to the tribes of the north until the age of their intercourse with the Romans, from whom they borrowed both the conception and the name of the sagulum, or "sail." The course of their migrations must have followed the valleys of the great rivers.

If southern Scandinavia is thus to be regarded as the original home of the Aryan languages, and the race which first spoke those languages, and which we may therefore call Aryan, is to be identified with the Scandinavian type, it follows that the further south and east we advance from this primary starting-point the less pure will the type become. It will be in the neighbourhood of that starting-point and in northern Europe that we shall expect to find the largest number of undiluted Aryan languages and the purest examples of the Aryan breed. In Greece and Armenia, in Persia and India we must look for mixture and decay. And such indeed is the fact. Mr. Wharton has found, by a careful analysis of the Greek lexicon, that out of 2,740 primary words only 1,580 can be referred with any probability to an Indo-European origin, while the prevailing racial type in ancient as in modern Greece was distinctly non-Aryan. Indeed, I am inclined to believe that the culture revealed by the excavations at Mykênæ, Tiryns, and on other prehistoric Greek sites belonged not to a Hellenic but to a 
pre-Hellenic population, and that the Aryan Greeks first made their appearance in Hellas at the epoch of what later tradition called the Dorian immigration. It was to the north that Greek legends pointed as the primæval home of the Hellenic race and civilisation, and Dôdôna ever continued to be revered as the oldest sanctuary of the Hellenic world. In India it is notorious that the Aryan-speaking Hindus entered the country from the north-west, and failed to spread far into the burning plains of the south. The date of their invasion is uncertain, but for myself I have grave doubts whether it was earlier than the eighth or even the seventh century B.c. At all events it was not until after the seventh century B.C., as we now know from the express testimony of the cuneiform inscriptions of Van, that the Aryan-speaking Armenians entered the land which now bears their name, and recent philological researches have confirmed the assertion of Greek writers that the Armenians were a colony of the Phrygians who had themselves emigrated from Thrace. Up to the closing days of the Assyrian empire the monuments make it clear that no Aryans had as yet settled between the Kurdish ranges on the east and the Halys on the west.

But while the extension into Asia of what I will now, following Penka's example, call the Aryan race, seems to be referred to a comparatively recent period, there is a curious fact which goes to show that the same, or a closelys allied, race once spread along the northern coast of Africa. On Egyptian monuments, which date back to the sixteenth century before our era, the Libyan tribes of this district are described and depicted as white. Their descendants are still to be found in the mountainous parts of the coast, those of Algeria being commonly known under the name of Kabyles. I saw a good deal of them last winter, and must confess to being greatly struck by their appearance. I had known, of course, that they belonged to the white race and were characterised by blue eyes and light hair, but I was not prepared to find that their complexion was of that transparent whiteness which freckles readily and is supposed to mark the so-called red Kelt. They are dolichocephalic, and as their skulls agree with those discovered in the prehistoric cromlechs of Roknia and other places it is plain that their distinctive features are not due, as was formerly supposed, to intermixture with the Vandals.

The cromlechs in which they once buried their dead are quite as remarkable as their physical characteristics. Cromlechs of a similar shape are found extending through Spain and western France to the northern portion of the British Isles. Since dolichocephalic skulls occur in connection with them, while the physical characteristics of the modern Kabyle resemble so strikingly those of a particular portion of the modern Irish population, we seem driven to infer that the Kabyle and the "red Kelt" are alike fragments of a race that once spread from Scotland and Ireland to the northern coast of Africa and interred its dead in chambers formed of five large blocks of stone. Though the custom of burying in these 
cromlechs continued into the bronze age, the majority of thern go back to the neolithic period.

Are we to suppose, then, that one stream of Aryan immigrants, after making its way to the west, wandered along the western coast of Europe, and eventually crossed the Straits of Gibraltar and took possession of Africa? Or are we to believe that the Aryan race of Southern Scandinavia was allied in blood, though not in language, with a population which inhabited the extreme west of Europe, and had, it may be, at the close of the glacial epoch, passed over to the neighbouring mountains of Africa? It must be remembered that the Kabyle complexion is not precisely the same as that of the Scandinavian. Both are white, but the skin of the one has a semi-transparent appearance, while the whiteness of the other may be described as mealy. It will be worth while to determine whether between the dolichocephalism of the Kabyle and the dolichocephalism of the Scandinavian any distinction can be drawn.

The question has a bearing on the origin of a part of our own population. I have already compared the Kabyle with the "red Kelt." But the expression "red Kelt," like most popular expressions, is by no means exact. It confuses in one two distinct types. The large-limbed, red-haired Highlander, who calls to mind the description given of the Kelts by the Latin historians, stands in marked contrast to the small-limbed, light-complexioned Kelt of certain districts in Ireland, whose skin is freckled rather than burnt red by the sun. The determination of the several racial elements in these islands is particularly difficult on account of the intermixture of population, and nowhere is the difficulty greater than in the case of the Keltic portion of the community. Long before the Roman conquest the intrusive Aryan Kelt had been intermarrying with the older inhabitants of the country, who doubtless belonged to more than one race, the result being that the so-called Keltic race is an amalgamation of races differing physiologically but dominated by a common moral and intellectual character-the consequence of subjection for a long series of generations to the same conditions of life. It has become a commonplace of ethnology that the so-called Keltic race includes not only the fair complexioned Aryan Kelt, but also the "black Kelt" or Iberian with dark skin, black hair and eyes, and small limbs. The subject, however, is much more complex than this simple division would imply. We have seen that under the "red Kelt" are included two distinct varieties; the "black Kelt" is equally irreducible to a single type, while the fact that two types of "red" and "black" recur in the same family-my own, for example-not only indicates their long-continued intermixture, but suggests the existence of intermediate varieties. The limitations and relations of dolichocephalism and brachycephalism within the race also need further investigation. I hope that this meeting, held as it is on the borders of what is still a distinctively Keltic country, may help to settle these and similar problems. 
Meanwhile I will conclude this address, which has already extended to an inordinate length, by directing your attention to two lines of evidence which have an important bearing on the question of the extent to which the Keltic element enters into the existing British population. A few years ago it was the fashion to assert that the English people were mainly Teutonic in origin, and that the older British population had been exterminated in the protracted struggle it carried on with the heathen hordes of ArgloSaxon invaders. The statement in the "Saxon Chronicle" was quoted that the garrison of Anderida, or Pevensey, when captured by the Saxons in A.D. 491, was all put to the sword. But it is obvions that the fact would not have been singled out for special mention had it not been exceptional, while it is equally obvious that invaders who came by sea can hardly have brought their wives and children with them, and must have sought for both wives and slaves in the natives of the island. Mr. Coote, in his "Romans of Britain," and Mr. Seebohm, in his "English Village Community," have pointed out the continuity of laws and customs and territorial rights between the Roman and the Saxon eras, presupposing a continuity of population, and anthropologists have insisted that the survival of early racial types in all parts of the country cannot be accounted for by the settlement of the Bretons who followed William the Conqueror, or of the Welsh who came into England when the penal laws against them were repealed by Henry VIII. But the advocates of the theory of extermination had always one argument which seemed to them unanswerable, and which indeed was the origin of their theory. The language of the Anglo-Saxons contains scarcely any words borrowed from Keltic. Such a fact was held to be inexplicable except on the hypothesis that the speakers of the Keltic dialects were all exterminated before any intercourse was possible between them and the invading Teaton.

But I think I can show that the fact admits of quite another explanation. Roman Britain was in the condition of Roman Gaul; it was a Roman province, so thoroughly Romanised indeed that before the end of the first century, according to Tacitus ("Agric.," 18-21), even the inhabitants of North Wales had adopted the Roman dress and the Roman habits of luxury. After four centuries of Roman domination it is not likely under these circumstances that the dialects of the British tribes would have resisted the encroachment of the Latin language any more than did the dialects of Gaul. The language, not only of government and law, but also of trade and military service, was Latin, while the slaves and servants who cultivated the soil were bound to understand the language of their masters. Moreover Britain was a military colony; the natives were drafted into the army, and there perforce had to speak Latin. If Latin had not been the language of the country at the time the Romans left it, the fact would have been little short of a miracle.

That it was so is certified by more than one piece of evidence. VOL. XVII. 
The inscriptions which have survived from the period of the Roman occupation are numerous; with the exception of three or four Greek ones, they are all in Latin. Of a Keltic language or dialect there is no trace. When the Romans had departed, and the inhabitants of Wales and Cornwall had been cut off from intercourse with the civilised world, Latin was still the ordinary language of the mortuary texts. It is only gradually that Keltic oghams take their place by the side of the Roman characters. When St. Patrick writes a letter to the Welsh prince of Cardiganshire, addressed not only to him but to his people as well, it is in the Latin language; when St. Germanus crosses into Britain to settle a theological controversy, and leads the people to victory against the Saxon invader, he has no difficulty in being understood; and the proper names of British leaders continue to be Roman long after the departure of the Roman legions. What clinches the matter, however, is the positive statement of Gildas, the British writer, the solitary witness who has survived to us from the dark period of heathen invasion. He asserts that the ships called "keels" by the Saxons were called longoe naves "in our language" ("nostra lingua"). ${ }^{1}$ In the middle of the sixth century, therefore, Latin was still the language of the Kelt south of the Roman Wall. Such being the case it is not Keltic but Latin words that we must expect to have been borrowed by AngloSaxon, if the British population, instead of being exterminated, lived under and by the side of their Teutonic invaders. Now these borrowed Latin words exict in plenty. They have come not only from the speech of the towns, but also from the speech of the country, proving that the country population must have used Latin like the inhabitants of the towns. In an interesting little book by Professor Earle on the Anglo-Saxon names of plants a list is given of the names of trees and vegetables that have been taken from a Latin source. Where the tree or the vegetable was one with which the invaders had not been acquainted in their original home, the name they gave to it was a Latin one, like the cherry or cerasus, the box or buarus, the fennel or feniculum, the mallow or malva, the poppy or papaver, the radish or radix. Such names they could have heard only from the serfs who tilled the ground for their new lords, not from the traders and soldiers of the cities. It is much the same when we turn to the names of agricultural implements which imply a higher order of culture than the simple plough or mattock, the name of which last, however, is itself of Keltic origin. Thus the coulter is the Latin culter, the sickle is the Latin secula. That other agricultural imple. ments bore Teutonic names proves merely that the Saxons and Angles were already acquainted with them before they had quitted their primitive seats.

The philological argument has thus been cut away from under the feet of the advocates of the theory of extermination, and

$$
1 \text { “ Hist.," p. } 23 .
$$


shown to tell precisely the contrary tale. It has disappeared like the philological argument by which the theory of the origin of the Aryans in Asia was once supposed to be supported. But there still remains one difficulty in our path.

This is the fact that the languages spoken in Wales, and till recently in Cornwall, are Keltic and not Latin. If Latin had been the language of the Keltic population of southern Britain when the Romans left the island, how is it that where the Keltic population still retains a language of its own that language is Keltic? The answer to this question is to be found in history and tradition. $\mathrm{Up}$ to the sixth century the Teutonic invaders gained slowly but steadily apon the resisting Britons. They forced their way to the frontiers of what is now Wales, and there their further course was checked. The period when this took place is the period when Welsh literature first begins. But it begins, not in Wales, but in Strathclyde or South-western Scotland, to the north of the Roman Wall. Its first records relate to battles that took place in the neighbourhood of Carlisle. From thence its bards and heroes moved southwards into North Wales. Tradition commemorated the event as the arrival in Wales of "Cunedda's men." The sons of Cunedda founded the lines of princes who subsequertly ruled in Wales, and the old genealogies mark the event by suddenly substituting princes with Welsh names for princes with Latin names. The rude Keltic tribes of Strathclyde came to the assistance of their more cultured brethren in the south, checking the further progress of the foreigner and imposing their domination and language upon the older population of the country. It is probable that the disappearance of Latin was further aided not only by the destruction of the cities and the increasing barbarism of the people, but also by the settlement of Irish colonies, more especially in South Wales. At all events the ruin of cities like Caerleon and Caerwent must be ascribed to Irish marauders. We can now explain why it is not only that Wales speaks Welsh and not Latin, but also why a part of the country. which, according to Professor Rhŷs, was mostly peopled by Gaelic tribes before the Roman conquest, speaks Cymric and not Gaelic. As for Cornish its affinities are with Breton, and since history knows of frequent intercourse between Cornwall and Brittany in the age that followed the departure of the Romans we may see in the Cornish dialect the traces of Breton influence.

The arrival of "Cunedda's men" and the re-Keltisation of Wales lead me to the second line of evidence to which I have alluded above. The bearing of the costume of a people upon their ethnography is a matter which has been much neglected. But there are few things about which a population-more especially in an early stage of society-is so conservative as in the matter of dress. When we find the Egyptian sculptor representing the Hittites of the warm plains of Palestine clad in the snow-shoes of the mountaineer we are justified in concluding that they musi have descended from the ranges of the Taurus, where the bulk of 
their brethren continued to live, just as the similar shoes with turned-up ends which the Turks have introduced among the upper classes of Syria, Egypt, and northern Africa point to the northern origin of the Turks themselves. Such shoes are utterly unsuited for walking in over a country covered with grass, brushwood, or even stones; they are on the contrary admirably adapted for walking on snow.

Now the dress of Keltic Gaul and of southern Britain also when the Romans first became acquainted with it was the same as the dress which "linguistic palæontology" teaches us had been worn by the primitive Aryans in their first home. One of its chief constituents were the braccee, or trousers, which accordingly became to the Roman the symbol of the barbarian. We learn, however, from sculptures and other works of art that before the retirement of the Romans from the northern part of Europe they had adopted this article of clothing, at all events during the winter months. That the natives of southern Britain continued to wear it after their separation from Rome is clear from a statement of Gildas ("Hist.," 19) in which he refers in no flattering terms to the kilt of the Pict and the Scot. Yet from within a century after the time of Gildas there are indications that the northern kilt which he regards as so strange and curious had become the common garb of Wales. When we come down to the twelfth century we find that it is the national costume. Giraldus Cambrensis gives us a description of the Welsh dress in his own time, from which we learn that it consisted simply of a tunic and plaid. It was not until the age of the Tudors, according to Lluyd, the Welsh historian of the reign of Elizabeth, that the Welsh exchanged their own for the English dress. $^{1}$ The Welsh who served in the army of Edward II at Bannockburn were remarked even by the Lowland Scotch for the scantiness of their attire, ${ }^{2}$ and we have evidence that it was the same a century later. ${ }^{3}$ If we turn to Ireland we find that in the days of Spenser, and later, the national costume of the Irish was the same as that of the Welsh and the Highland Scotch. The knee-breeches and sword-coat which characterise the typical Irishman in the comic papers are surrivals of the dress worn by the English at the time when it was adopted in Ireland.

The Highland dress, therefore, was once worn not only in the Scotch Highlands and in Ireland, but also in Wales. It characterised the Keltic parts of Britain with the exception of Cornwall and Devonshire. Yet we have seen that up to the middle of the sixth century, at the period when Latin was still the language of the fellow-countrymen of Gildas, and winen "Cunedda's men " had not as yet imposed their domination upon Wales, the old Keltic dress with trousers must have been the one in common use. Now we can easily understand how a dress of the kind could

1 “The Breviary of Brytaine," Twyne's translation, page 35 (ed. 1573).

2 Barbour's "Bruce," ix, pages 600-603.

3 See Jones" "History of the County of Brecknock, vol. i, page 283 ; curip. "Archæologia Cambrensis," 5th series, No. 7 (I885), page 227. 
have been replaced by the kilt in warm countries like Italy and Greece; what is not easily conceivable is that such a dress could have been replaced by the kilt in the cold regions of the north. In warm climates a lighter form of clothing is readily adopted; in cold climates the converse is the case.

I see, consequently, but one solution of the problem before us. On the one hand, there was the distinctive Keltic dress of the Roman age, which was the same as the dress of the primitive Aryan, and was worn alike by the Kelts of Gaul and Britain and the Teutons of Germany; on the other hand, there was the scantier and colder dress which originally characterised the coldest part of Britain, and subsequently mediæval Wales also. Must we not infer, in the first place, that the aboriginal population of Caledonia and Ireland was not Keltic-or at leust not Aryan Keltic-and, secondly, that the dominant class in Wales after the sixth century came from that northern portion of the island where the kilt was worn? Both inferences, at all events, agree with the conclusions which ethnologists and historians have arrived at upon other grounds.

Perhaps what I have been saying will show that even a subject like the history of dress will yield more results to ethnological study than is usually supposed. It will be another illustration of the fact that the student of humanity cannot afford to neglect any department of research which has to do with the life of man, however widely removed it may seem to be from science and scientific methods of enquiry. "Homo sum; humani nihil a me alienum puto."

ON the Notes sounded by Mr. GaLton's Whistues for testing the limit of AUdibILITY of Sound.

$$
\text { By W. N. Shaw, Esq., M.A. }
$$

IN order to test the limit of audibility of sound, an adjustable whistle is made by the Cambridge Scientific Instrument Company on the plan designed by Mr. Galton some 10 years ago. It is a whistle with a very narrow pipe; the length of the pipe can be adjusted by means of a piston, a wire $73 \mathrm{~mm}$. in diameter, sliding in the pipe. This sliding wire carries a disc, and the frame to which the whistle is attached and in which the outer end of the wire piston rests, carries a parallel disc. As the piston is pushed in, these two discs approach each other. Their distance apart can be measured by inserting a graduated wedge, and gives at once the length of the pipe of the whistle. The whistle is blown by compressing a small india-rubber bladder attached to it. The apparatus is used to determine the pitch of the highest note audible by a particular person in the following manner. The piston is adjusted till the vibration produced by the whistle is just inaudible; the distance between the discs is then read, giving a length of whistle 